\title{
Epidemiologic study on the factors affecting the incidence of asthma and allergy with emphasis on arthropod allergens in patients referring to Imam Reza Clinic of Asthma and Allergy in Shiraz, 2016
}

\author{
Shahriari-Namadi $\mathbf{M}^{\mathbf{1}}$, Azizi $\mathbf{K}^{\mathbf{2}}$, Djaefar Moemenbellah-Fard $\mathbf{M}^{3}$, Soltani $\mathrm{A}^{\mathbf{4}}$ \\ 1. MSc of Medical Entomology and Vector Control, Department of Medical Entomology and Vector Control, School of \\ Health, Shiraz University of Medical Sciences, Shiraz, Iran. ORCID ID: 0000-0002-8055-0998 \\ 2. Professor of Medical Entomology and Vector Control, Research Center for Health Sciences, Institute of Health, \\ Department of Medical Entomology and Vector Control, School of Health, Shiraz University of Medical Sciences, Shiraz, \\ Iran. \\ 3.Associate Professor of Medical Entomology and Vector Control, Research Center for Health Sciences, Institute of Health, \\ Department of Medical Entomology and Vector Control, School of Health, Shiraz University of Medical Sciences, Shiraz, \\ Iran. \\ 4. Associate Professor of Medical Entomology and Vector Control, Research Center for Health Sciences, Institute of Health, \\ Department of Medical Entomology and Vector Control, School of Health, Shiraz University of Medical Sciences, Shiraz, \\ Iran (Corresponding Author), Tel:+989126059289, Email:abu2sol@yahoo.com, ORCID ID: 0000-0003-0717-2561
}

\begin{abstract}
Background and Aim: Asthma and allergy caused by arthropods are among the most common disorders which affect millions of people around the world. Among these diseases, respiratory allergic diseases and inhaled allergens are of particular importance. In this study we investigated all of the biotic and a biotic factors affecting the incidence and prevalence of allergen-related diseases, with emphasis on the arthropods allergens in the living environments of the patients referring to Imam Reza Clinic of Asthma and Allergy in Shiraz.
\end{abstract}

Materials and Methods: We selected 100 patients who had positive allergy skin tests to at least one of the house dust mites or cockroaches randomly. After informed consent, the patients filled out a previously designed questionnaire.

Results: Place of residence (city and village) and type of air-conditioning system showed a significant relationship with the severity of contamination with cockroaches in the settlements of the patients ( $\mathrm{P}$ value $=0.028$ and 0.007$)$. There was a significant relationship between the place of residence and the presence of mites $(\mathrm{P}$ value $=0.001)$. Also lighting and ventilation of the patients' houses showed a strong correlation with the presence of mites. All (100\%) of the places in which mites were found had a poor and very poorcondition in regard to lighting and ventilation.

Conclusion: Lack of adequate light and ventilation in the patients' houses found to be the main causes of asthma and allergy in the patients. In general, due to the high abundance of some arthropods such as flies (Diptera), ant, silver fish, etc. in the houses of these patients, it can be assumed that arthropods other than mites and cockroaches may exacerbate allergic complications in the susceptible patients.

Keywords: Epidemiology, Asthma and allergy, Allergen, Arthropods, Shiraz

\section{Received: Feb 5, 2019 Accepted: July 7, 2019}

How to cite the article: Shahriari-Namadi M, Azizi K, Djaefar Moemenbellah-Fard M, Soltani A. Epidemiologic study on the factors affecting the incidence of asthma and allergy with emphasis on arthropod allergens in patients referring to Imam Reza Clinic of Asthma and Allergy in Shiraz, 2016. SJKU 2019;24(4):68-85.

Copyright (C) 2019 the Author (s). Published by Kurdistan University of Medical Sciences. This is an open access article distributed under the terms of the Creative Commons Attribution-Non Commercial License 4.0 (CCBY-NC), where it is permissible to download, share, remix, transform, and buildup the work provided it is properly cited. The work cannot be used commercially without permission from the journal. 


\section{بررسى إيدميولوزيك عوامل تاثير تذار بر بروز آسم و آلرزى با تاكيد بر بند پايان آلرثن در بيماران مراجعه كننده به كلينيك تخصصى آسم و آلرزى امام رضا شيراز در سال هوسأ}

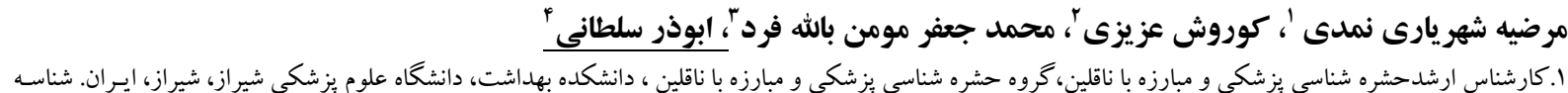

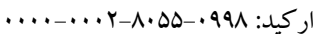

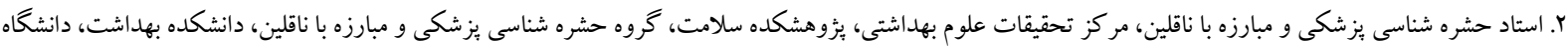
علوم يزشكى شيراز، شيراز، ايران.

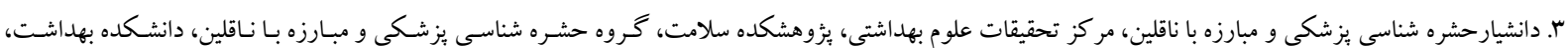
دانشكاه علوم يزشكى شيراز، شيراز، ايران.

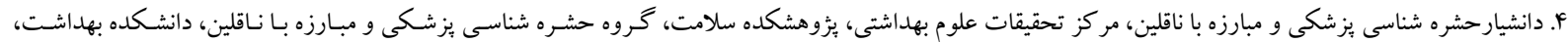

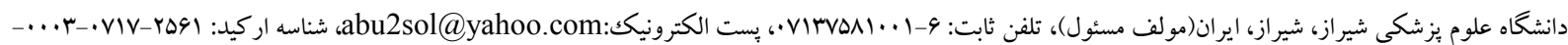

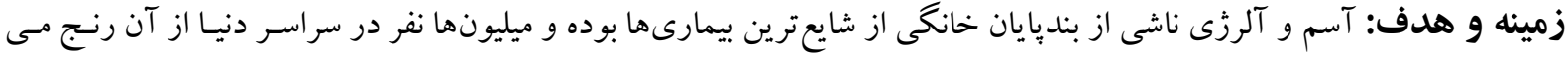

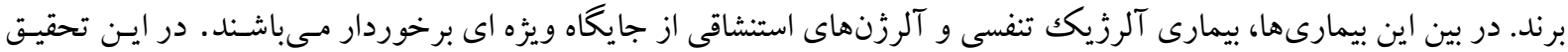

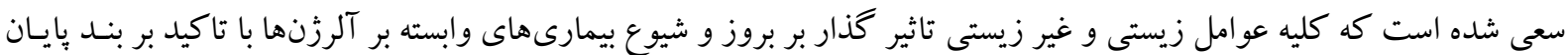

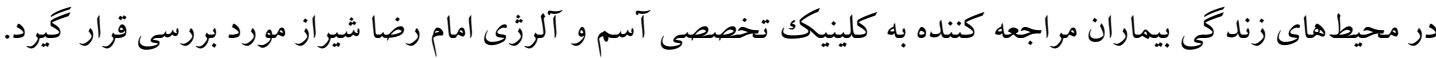

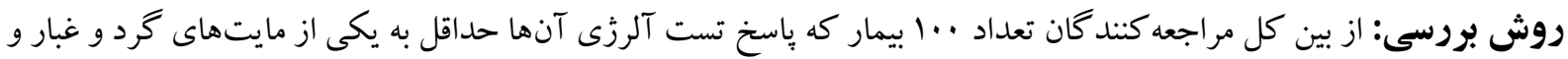

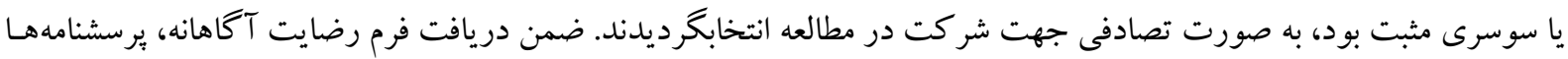

$$
\text { جهت تكميل شدن به آنها ارائه گرديد. }
$$

يافتها: بر اساس نتايج بدست آمده مشخص شد كه بين محل زندكى (شهر و روستا) افراد و نوع سيستم خنكك كننده با شدت

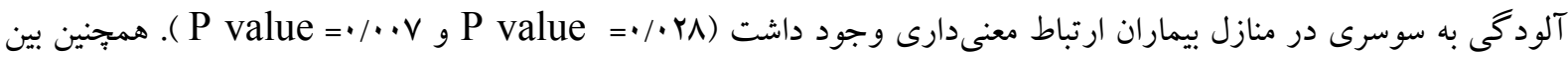

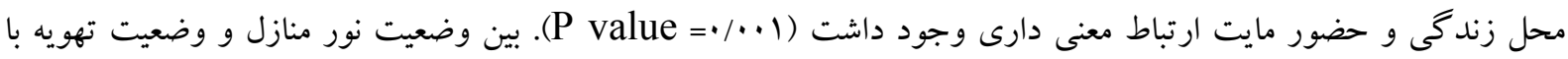
وجود مايت ارتباط بسيار شديد وجود داشت،كه ..1./منازلى كه در آنها مايت صيد شده بود داراى وضعيت بد و بسيار بد از نظر نور و تهويه بودند. نتيجه كيرى:عدم وجود نور كافى و تهويه مناسب در منازل علت اصلى بـروز آسـم و آلكرزى در بيمـاران مـورد مطالعه بـود.در مجموع با توجه به وفور نسبتا بالاى برخى از بنديايان مانند دوبالان، مورجه، ماهى نقره اي و ... در منازل بيماران شهر شيراز، مى تواند اين فرضيه قوت يابد كه شايد ساير بنديايانغير از مايتها و سوسرىها كه در منازل حضور دارند بتوانند باعث تشديد عوارض فئر آلرزيكك در اين گونه از بيماران حساس شوند ئد كليد وازه ها : إيدميولوزى، آسم و آلرزى، آرزذن، بنديايان، شيراز

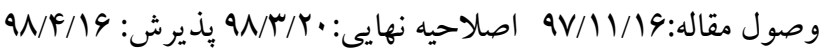




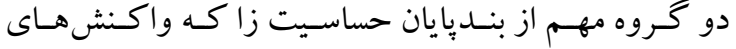
يوستى / تنفسى متنوعى را در بدن انسان به وجود آوروده و در بهر طولانى مدت منجر به اختلالات آلرزيكك در برخى افراد مستعد مى تواند شوند، هيره ها ( مايتها) و سوسرىها بـوده كه به وفور درون اماكن مسكونى مسىتوانتـد وجـود داشتهـ (House Dust Mite = باشـندمايت گـردو غبـار

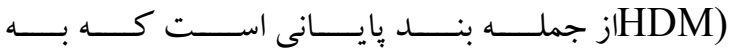

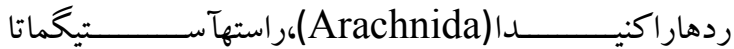
Pyroglyphidae و خلق داشته و (Astigmata) در مناطق گرم و مرطوب رشد مسى كنـــ(F). ايـن بنـد بِايـان موجوداتى كو جكك و ميكروسكويى هستند كـه انـدازه آنها

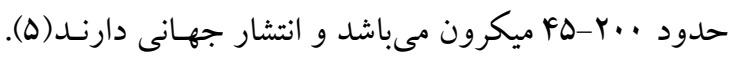

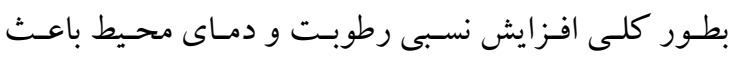

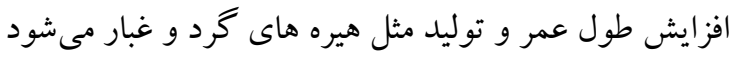

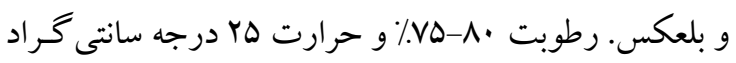
مناسبترين محيط براى زاد و ولد آنهاست. مايت هـايى كـه ورجه در كف اتاقهاى نشيمن زندگى مى كنند، دراواخر تابستان و اوايل باييز حداكثر تراكم را دارند (9).

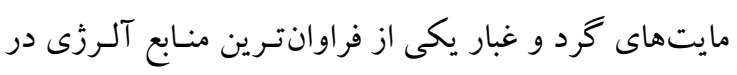

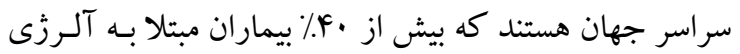

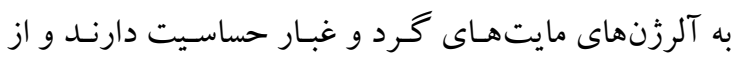

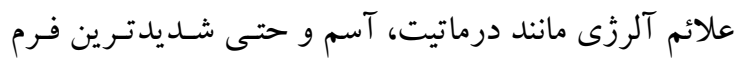
آلرزى تنفسى را دارا هستند (V).

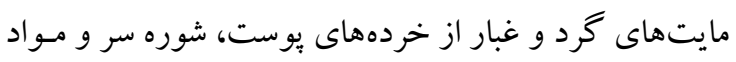

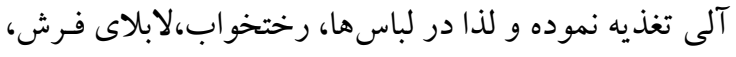

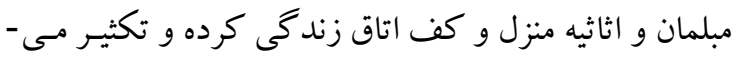

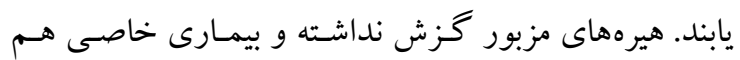

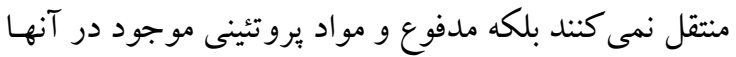

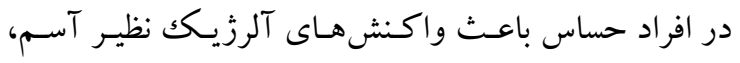
رينـين آلرزيـك دائمسى و درماتيـت اتوييكك (اكزمـا) مسى

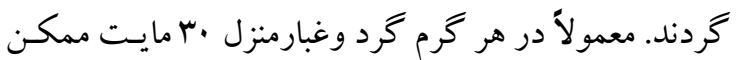

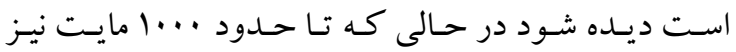

مقدمه امروزه با ييشـرفتكنولوزى و افزايش آلـودكى هـاى زيسـت

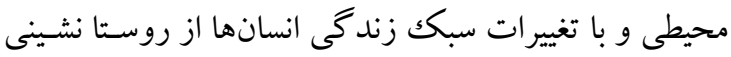
به شهر نشينى، بيمارىهـاى بازيديـــ و نـو يديـدى بـا شـدت فـراوان در بـين جوامـع انسـانى در حسال كسـترش هسـتند. بيمارىهاى آلرزى يكى از مهمترين بيمارىهايى هستند كـه جامعهى جهانى را در گير خود كرده است. مطالعات مختلفى به اهميت بيمارىهاى آلرزيك و اثرات سو آن براى جوامع اشاره كردهاند.بنديايان تقريبـا در تمـام اكوسيستم هـا بـويزه . محيط هاى مسكونى انسان حضور فعـال داشـته و همزيستى آنها با انسان در اماكن مسكونى به رشد و تكثير آنها كمك بسزايى نموده، كه محيطى بيوسته يكنواخت از لحاظ عوامل غير زيستيبراى اسكان، رشد و بارورى اين آفات فراهم مسى نمايـــ. وجــود آب، غـذا و سـريناه مناسـب درون امــاكن مسكونى باعث شده تا جمعيت بنديايان زياد شده و در نتيجه منجر به تماس مستقيم بين موجودات و يا بقايايشان بـا انسـان

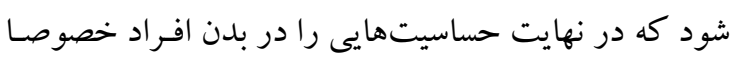
نوزادان ممكن است ايجاد نمايد. نقش بندييايان در تحريك سيستم ايمنى بدن انسان و ساير مهرهداران محـرز كرديـده و

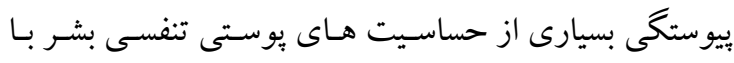
حضـور بنــديايان امـرى بـــيهى بـوده كـه مسـتندات آن در بسيارى از كتـب، رسـاله هـا و مقـالات انتشـار يافتـه انـد( (1).

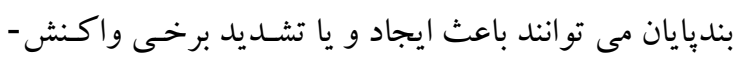
هاى آلرزيكك در انسان گردند.در هر حال تعداد منحصـر بـه فردى از انواع بنــديايان همزيسـت بـا انسـان هـا در خانـه هـا

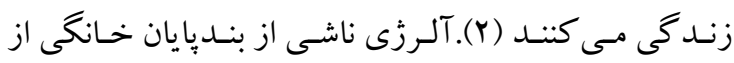
شايعترين بيمارىها بوده و ميليونها نفر در سراسر دنيا از آن رنج مىبرند. در بين اين بيمارىها، بيمارى آلرزيـك تنفسى تهـ

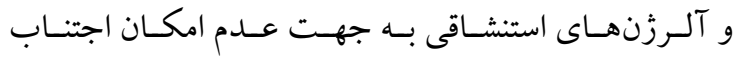
اختيارى، وفور و گرفتارىهاى متعددى كه ايجاد مسى كنــد، از جايگاه ويزه اي برخوردار مىباشند (r). 
قرار گيرى در معرض گرد و غبار حاوى آلرزنهاى مايتها،

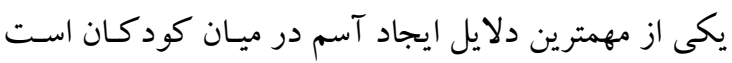

مواردى از آثار بيمارىهاى ناشى از تماس انسان، سوسرى -

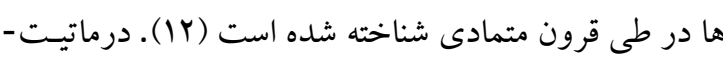

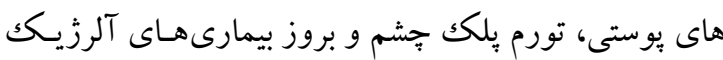

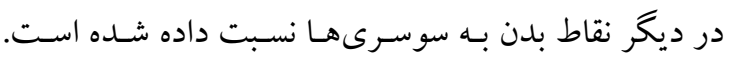

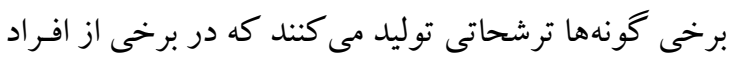

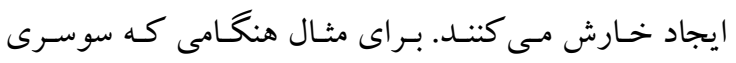
Eurycotis floridana خارج مى كند كـه ممكـن اسـت روى بوستـهـاى حسـاس

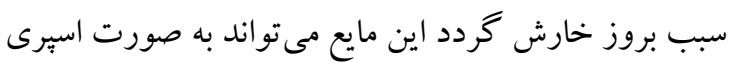

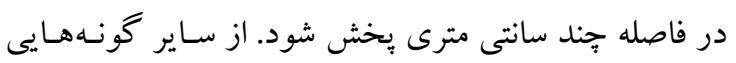
كه ترشحات بودار توليد مى كنند مى توان به Diploptera punctate, Rhyparobia maderae (rا). خو اص تاول زايى سوسرىها به جربى كو تيكول يا بـه ترشحاتى از قطعات دهانى آنها نسبت به داده مىشود (If).

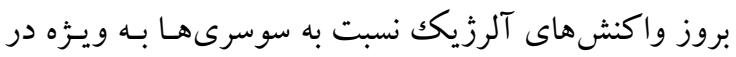

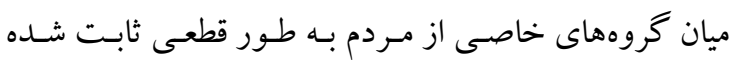
است. مطالعات وسيعى كه درباره اين مواد انجام شـده نشـان مىدهد آن دسته از افرادى كه در برابر سوسرىها واكنش هاى آلرزيكى يوستى وتنفسى نشان مىدهنـد در مقايسه بـا

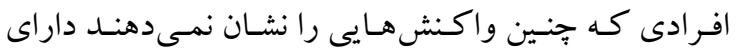
سطوح بالايى از آنتى بادىهاى مخصوص سوسرىها هستند

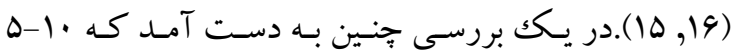
درصد يكك جمعيت عمومى به مواد آلرزن سوسرى موجيود در گرد و غبار منزل واكنش مثبت نشان دادند (IV IN ). اهميـت آلـرزىزايسى سوسـرى هــاو وبيامـدهاى آن در آسـم دوران كودكى از دهـه ، ل199 بـه خـوبى مستيند شـده است. واكنشهاى آلرزيكدر نتيجه حساسيت اوليه به آنتى زن هـا

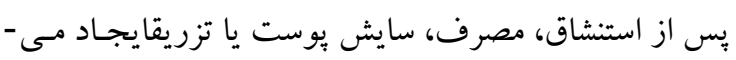

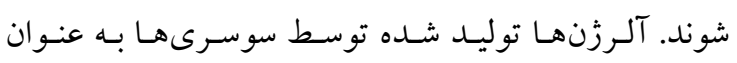

كزارش شده است.بعضى گزونههـا بصورت سـر گردان ويـا

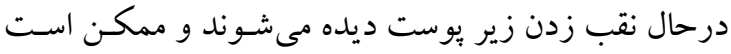

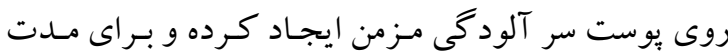
بيش از V سال روى سر باقى بمانند (^).

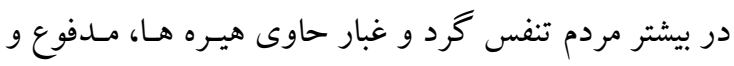

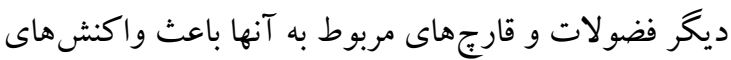

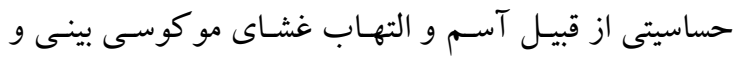
التهاب ها و خارشهـاى يوستى مسىشـود. تعـداد زيـادى از

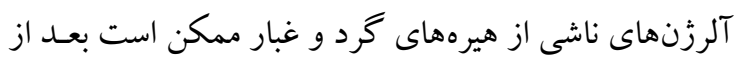
مر تب كردن رختخواب وارد هوا شوند. برخى ديخر از هيره -

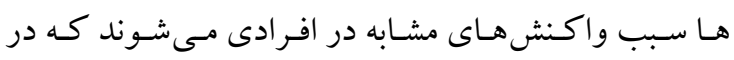

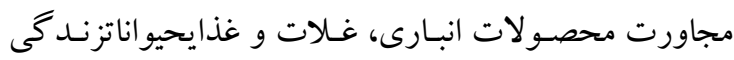

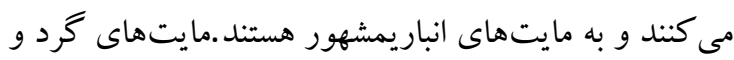
غبار از سلولهاى مرده يوست بدن انسانبه عنوان غذا استفاده

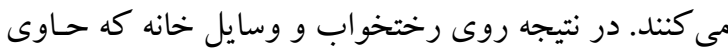
سلولهاى مرده يوست بدن هستند، بـه ميزان زيـادى وجـود

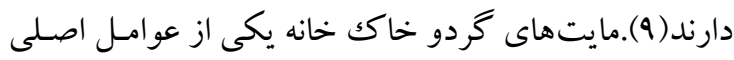
ايجاد حساسيت هستند. آلرزىهايى كه مايتهاى موجود در

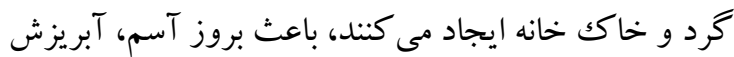
بينى، ريزش اشـك از جشـم، عطسه، مشـكلات تنفسى و التهاب يوستى مسى شـود. بـه جز مايـت ها،سـاير بنــ بايـان

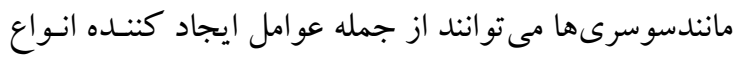
مختلف آلرزى ها باشند. علاوه بر آن، حيوانات دست آمست آمـوز

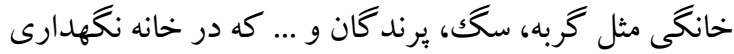

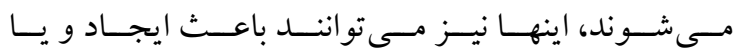
تشديد آلرزيشوند. همجنين استفاده از دستخاه بخور در منازل

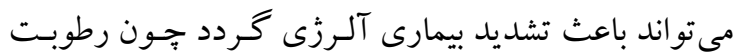

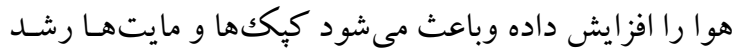
وتكثير ييدا كننديا كولرها كه در تابستان روشـن مسى شـوند يراز مايت، غبـار و كيكبـوده و بايستى هرسـال يوشـال آنها

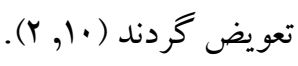


آنتى زن موجود در گرد وغبار خانه ها مىباشند كه در ايجاد واكنشهـاى آلرزيـك خصوص صـا رينيـت آلرزيـك، آسـم و اخزما و احتمالا كهير نقش مهمى را ايفامى كند (Y) (Y). Keren

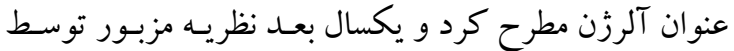
Cooke تأييد شد، ولى آلرزىزايسى معلوم نبود، تـا اينكـه Voorhorst غبار را مسئول آكرزى گردد و غبار معرفى كردند (Tr, YY). Fakoorziba داشت كه: تحقيقات انجام شده توسط Arlian و همكاران

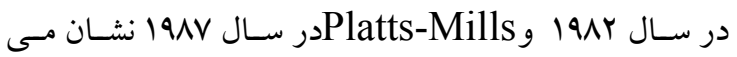
دهد كه مهمترين آلرزن مورد نظر براى ايجاد آسـم و سـاير واكنشهاى آلرزيك فوق الذكر، هيرهاى گرده و غبـار بـه-

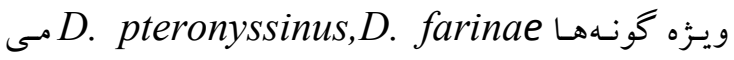
باشند. اخيراً موارد متعـددى از آلـرزى نسـبت بـه هيـهـهـاى Acarus siro, Glycyphagus destructor كار گر انى كه با يونجه سـر و كـار داشـته انــ مشـاهده شـده اسـت Armentia و همكـاران در سـال 1994 ســهـ مـورد

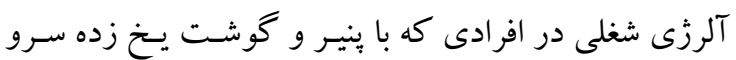

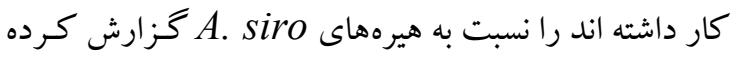

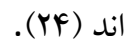

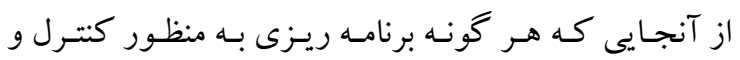

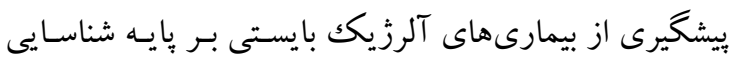
دقيق و علمىى، تشخيصـو اقـام بـه موقع در زمينه شـناخت

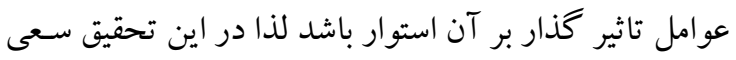
شده است كه كليه عوامل زيستى و غيرزيستى تاثير كذار بـر

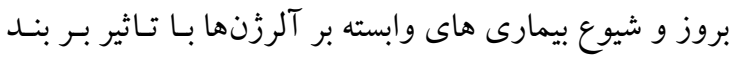

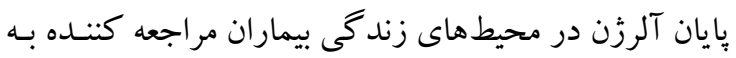
كلينيك تخصصى آسـم و آلرزى امـام رضا شـيراز مـورد

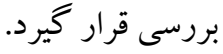

آلرزنزيست محيطى قابل تـوجهى در جوامع مـدرن شـناخته

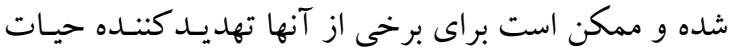
باشد. در ميان افراد مبتلا به آسم، حدود نيمى از منـازل آنها آلوده به سوسرىها هستند. بعضى از يروتئينهـاى آلرزيكك

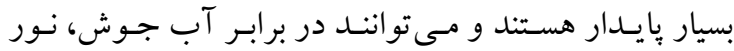
ماوراء بنفش و تغييراتpH مقاومند، و درطى جند دهه باقى

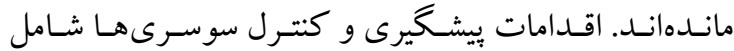

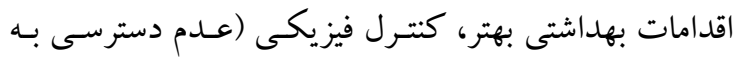

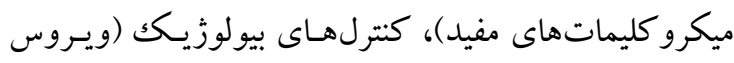

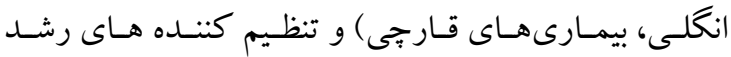
حشرات براى جلو گيرى از توليد مثل آنها بسيار موثر هستيتن

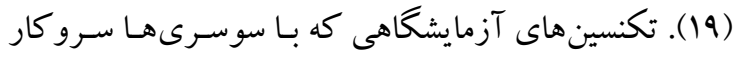

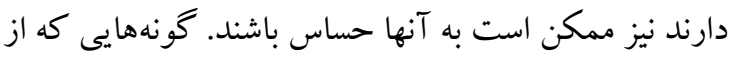

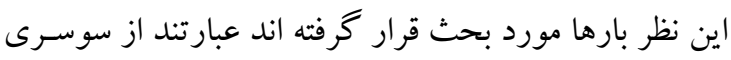
آمريكايى و سوسرى آلمـانى، ولى همـان طور كـه در بـانلا

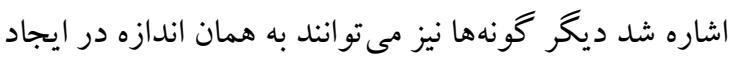

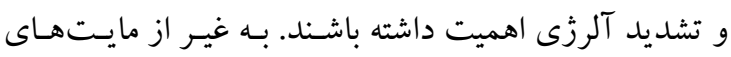
گرد و غبـار و انبـارى (dust and storage mites) همجِنين سوسرىها بسيارى از بند بايان ديخر نيز به عنو ان بند

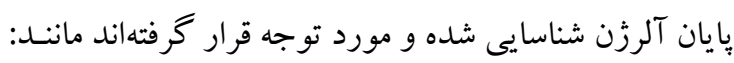

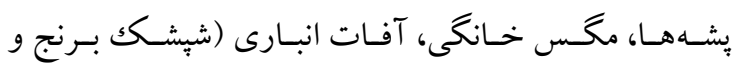

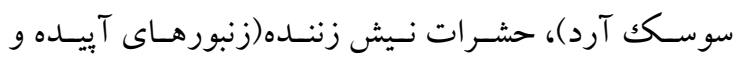

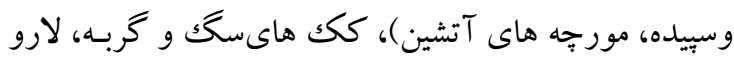
يروانسه، سـاس تختخـواب، انسواع مختلـف شـب قـرهــا،

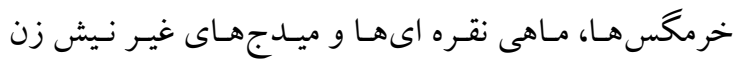

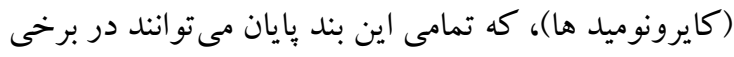

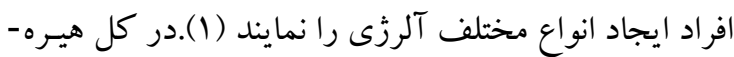

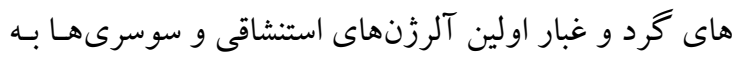
عنوان دومين عامل آلرزن شناخته شده اند (.r).

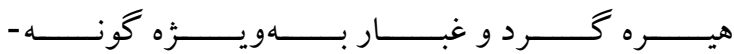

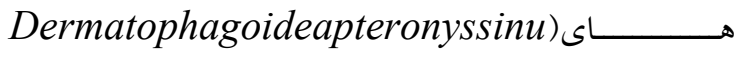
و (Dermatophagoidea farinae, عمـدهترين منـابع 
در تعيـين شـدت آلـودگى منـازل بـه سوسـرىهـا در محلـ

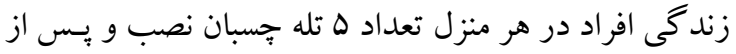

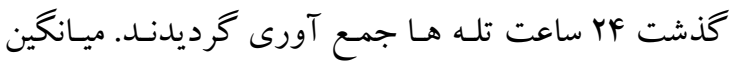
نوع مطالعه

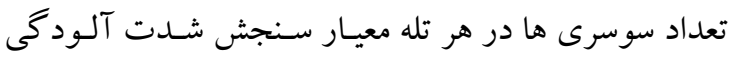
اين مطالعه به روش توصيفى و تحليلى صورت پـــيرفت. بـر

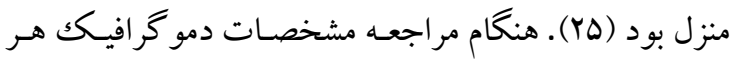

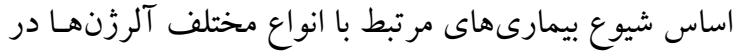
بيمار شامل سن، جنسيت، نوع شغل، ميزان تحصيلات، محل

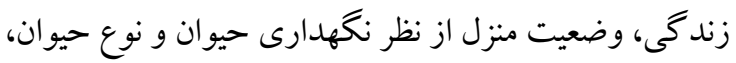

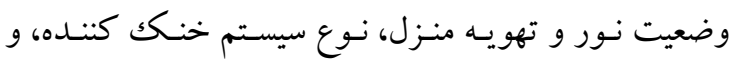

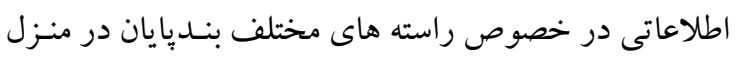
هر بيمار در قالب يك جِك ليست تصويرى تكميل گرديد.

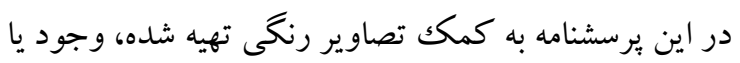

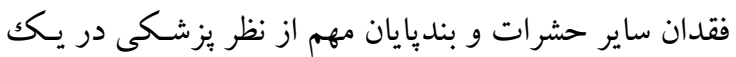

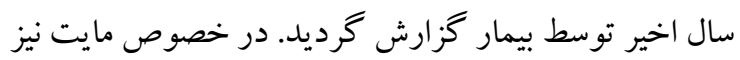
از منازل بيماران توسط جارو برقى مخصوص در هر منزل بـهـ

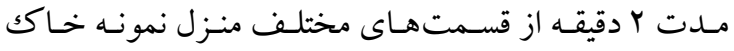

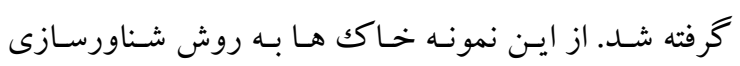
مايتها جدا سـازى و توسط كليـد هـاى معتبر تشخيصى،

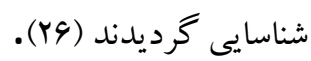

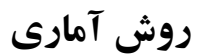
نتايج حاصل ازيرسشـنامه در نـرم افزار اكسـل وارد شـده و

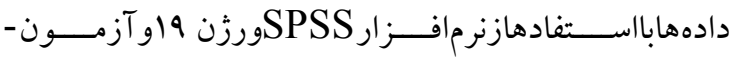

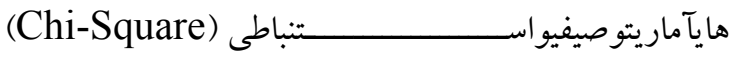

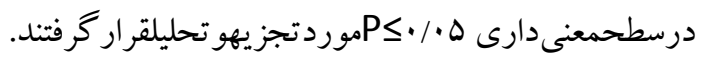

\section{يافتهها}

در اين مطالعه سن بيمارانى كه منازلشان از لحساظ آلودخى

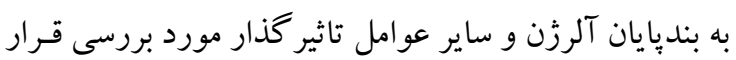
كرفت به اين صورت مىباشد كـه حسداقل سـن بيمـاران 10

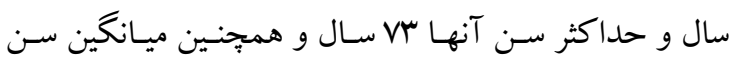

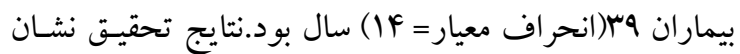
داد كه نسبت جنسيتى بيماران شركت كننده در اين مطالعه، شهر شيراز درمطالعات ييشين و همجنـين طبق نظر مشـاور آمارى تحقيق از بين كل بيماران مراجعه كننده بـه درمانغـاه

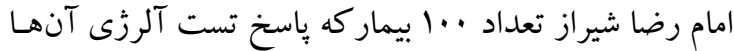

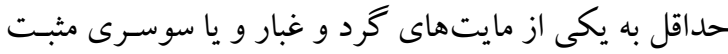

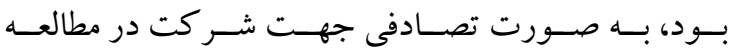

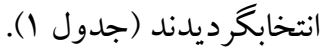

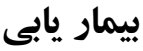
به اين افراد قبل از شروع مطالعه توضيحاتى به صورت تلفنى ارائه شد و يس از اعلام مو افقت آنها به منازلشـان مراجعهه و ضمن دريافت فرم رضايت آكاهانه برسشنامهها به آنها جهت

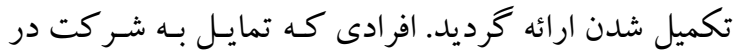
مطالعه را نداشتند از مطالعه حذف و عمليات نمونهه بردارى تا زمان كامل شدن حجم نمونه ادامه يافت.يرسشنامه براساس

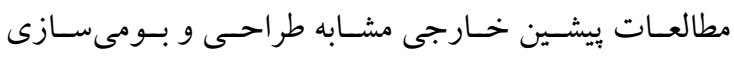

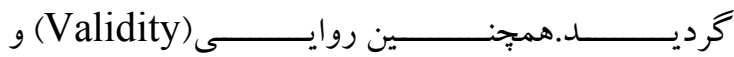
بايايى(Reliability) بـر اسـاس مطالعهاى بـايلوت كـه در

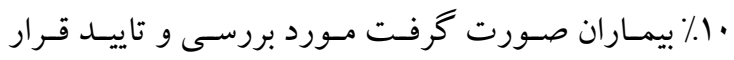

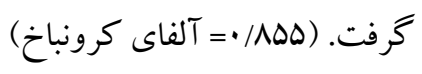

\begin{tabular}{|c|c|c|c|c|c|}
\hline \multicolumn{6}{|c|}{ جحاسبه اندازه فرمونه محاسبه حجم بر نمونه } \\
\hline Power & z-score & Precision & variance & $\mathrm{p} 1$ & $\mathrm{p} 1 *(1-\mathrm{p} 1)$ \\
\hline . 1 A & 1/99 & $\cdot / 11$ & .119 & $\cdot / r$ & $\cdot / 1$ \\
\hline حجم & 1../VYAG & & & & \\
\hline نمونه & & & & & \\
\hline
\end{tabular}

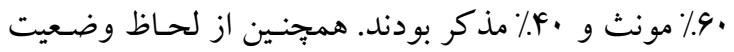




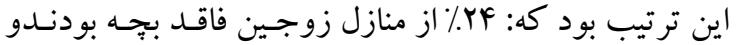

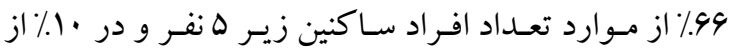
منازل تعداد ساكنين بالاى ه نفر بود. درصد آلود گیى منـازل به بند پايان مختلف و شدت آلودگى آنها از ايـن امـاكن در

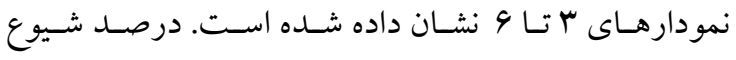
آلودگى به مايت در منازل مسكونى بيماران تحت مطالعه هـ/

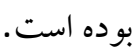

تاهل بيماران،مشخص شد كه VF٪ از كل افراد مورد بررسى

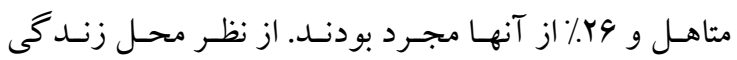

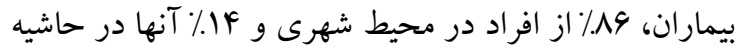

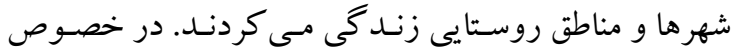

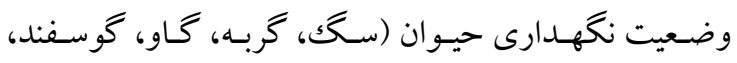
يرند گان زينتى، ماكيان تخم گحذار و ...) در منـازل، از كليـه

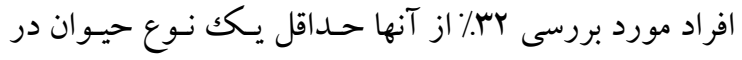

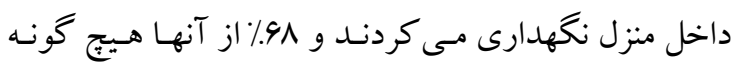
تمايل به نخهدارى حيوانات در منازلشان را نداشتند. اطلاعات در خصوص نوع حيوان نخهدارى شـده در داخـل منزل در نمـودار (1) نشـان داده شـده اسـت.بـر اسـاس نتـايج

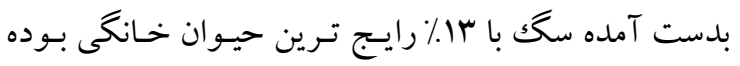
است كه بيماران با آن تماس داشته اند. در خصوص ميزان تحصيلات افراد شركت كننده در مطالعه.

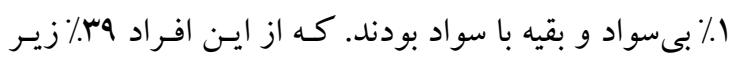

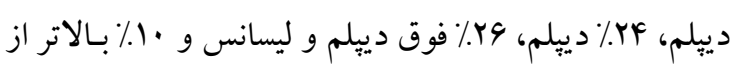

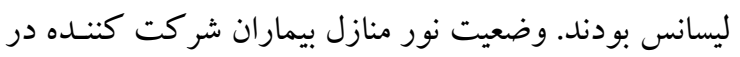
ايسن مطالعـه بـا استفاده از نـور سـنج ( Lux meterTes

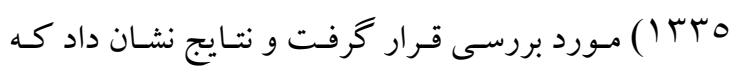

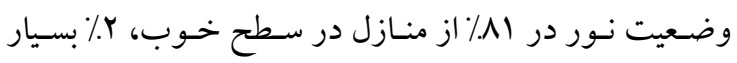

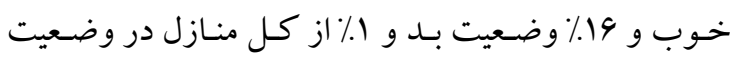
خيلى بد از لحاظ نور گيرى قرار داشتند. همجنـين وضسعيت

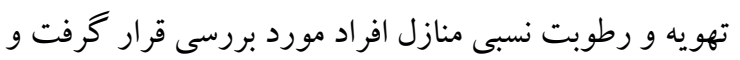

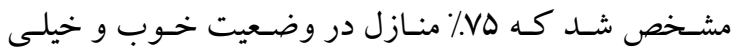
خوب، rr/\% در وضعيت بد و rّ٪ از منازل در حالت بسيار بد قرار داشتند. در خصوص وضعيت نوع بوشش منازل از كليه

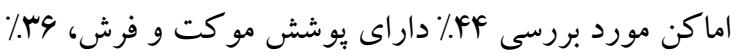

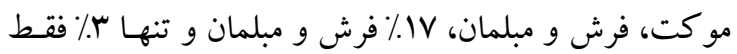
فرش داشتند.

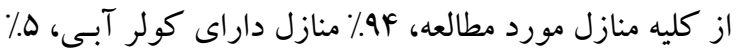

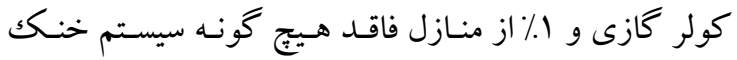
كننده بود. تعداد ساكنين در منازل بيماران مـورد بررسى بـهـ 


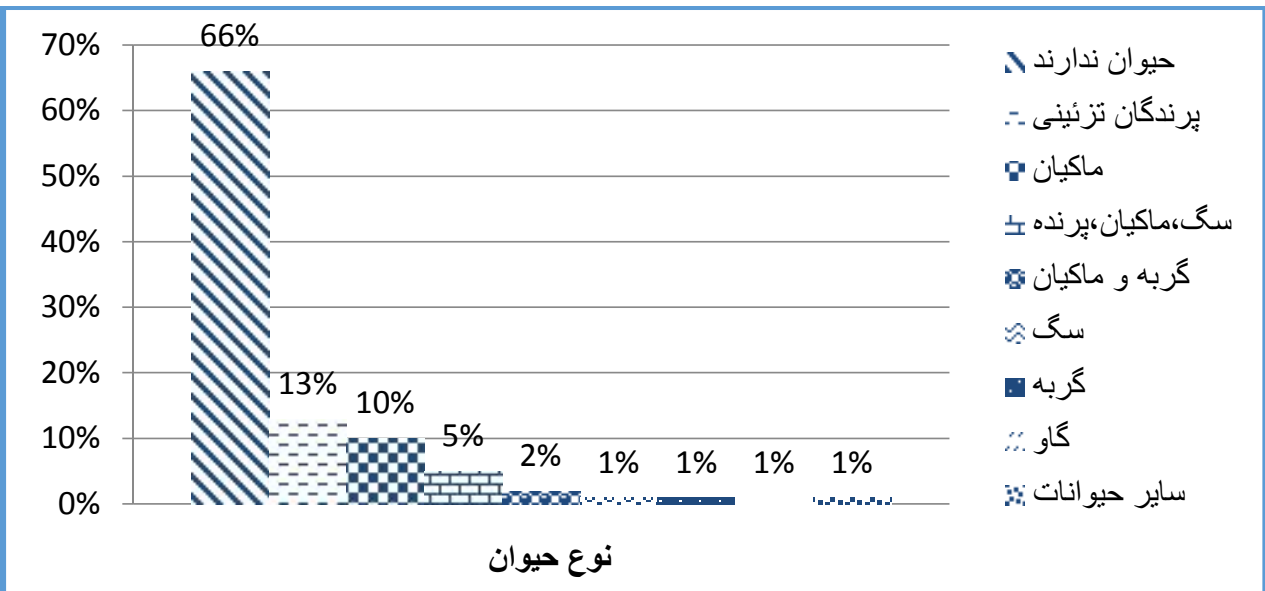

نمودار ا: درصد نخهدارى حيوانات خانكى مختلف در منازل بيماران تحت مطالعه

از نظر وضعيت و نوع شغل، بيماران مورد بررسى قرار كرفتند و بيشترين سهم مربوط به افرادى بود كه خانه دار بودنــ (ها؟٪) و هـ/ از بيماران در شغلشان مستقيما با حيوانات در تماس بودند (نمودار Y).

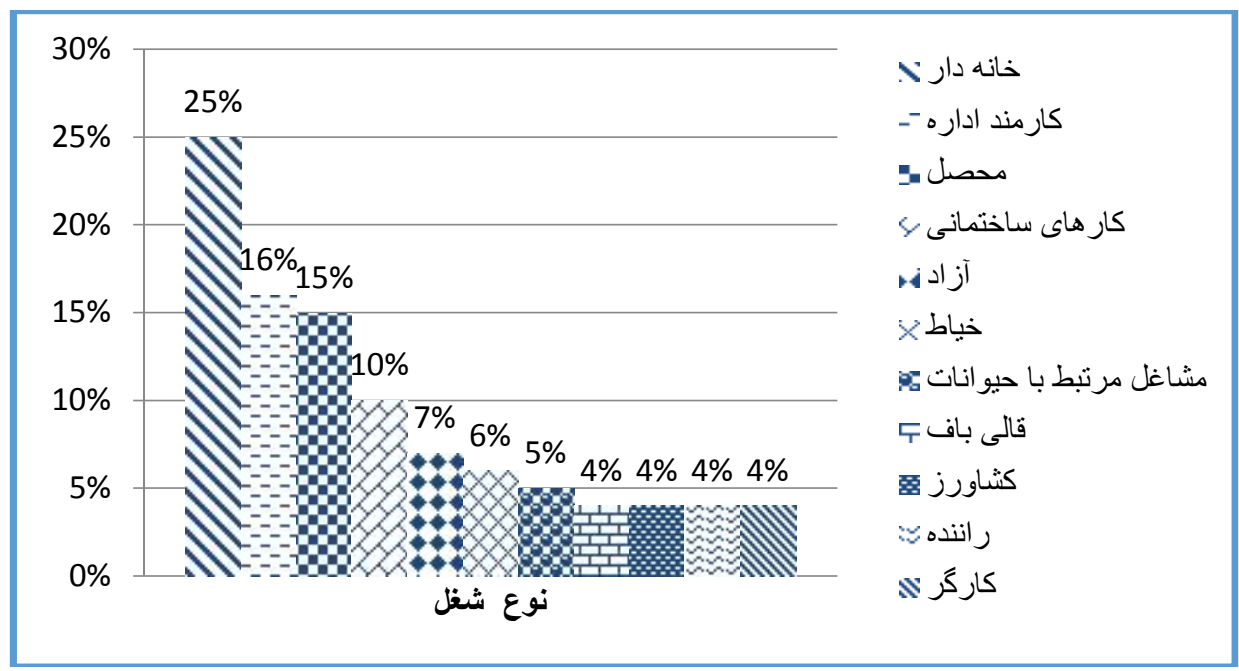

نمودار ז: وضعيت نوع اشتغال بيماران تحت مطالعه 


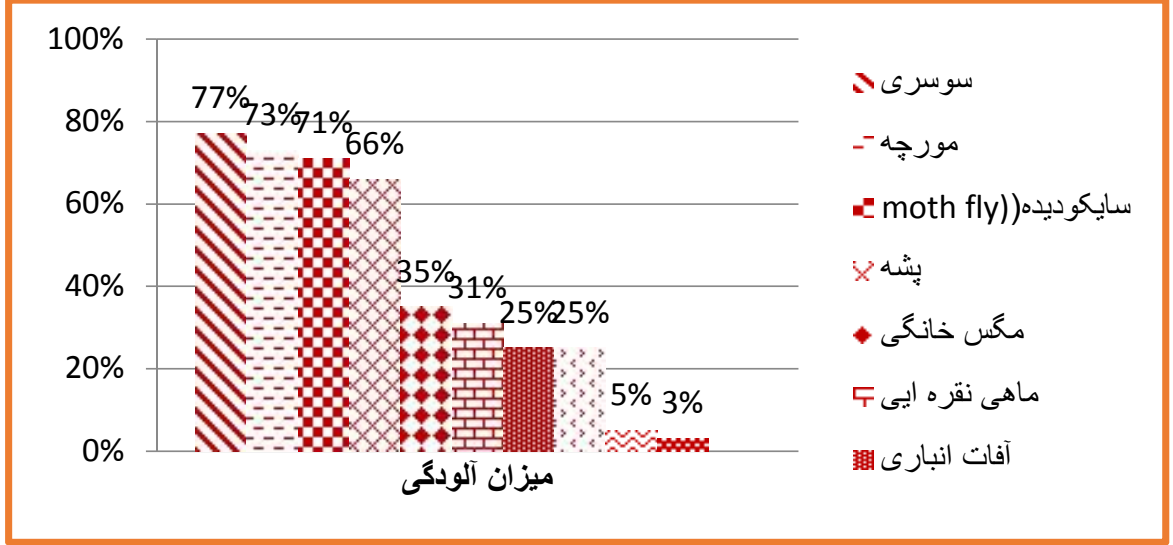

نمودار سا: درصد آلودگى به بنديايان مختلف در منازل بيمارانى كه مورد بررسى قرار گرفته است

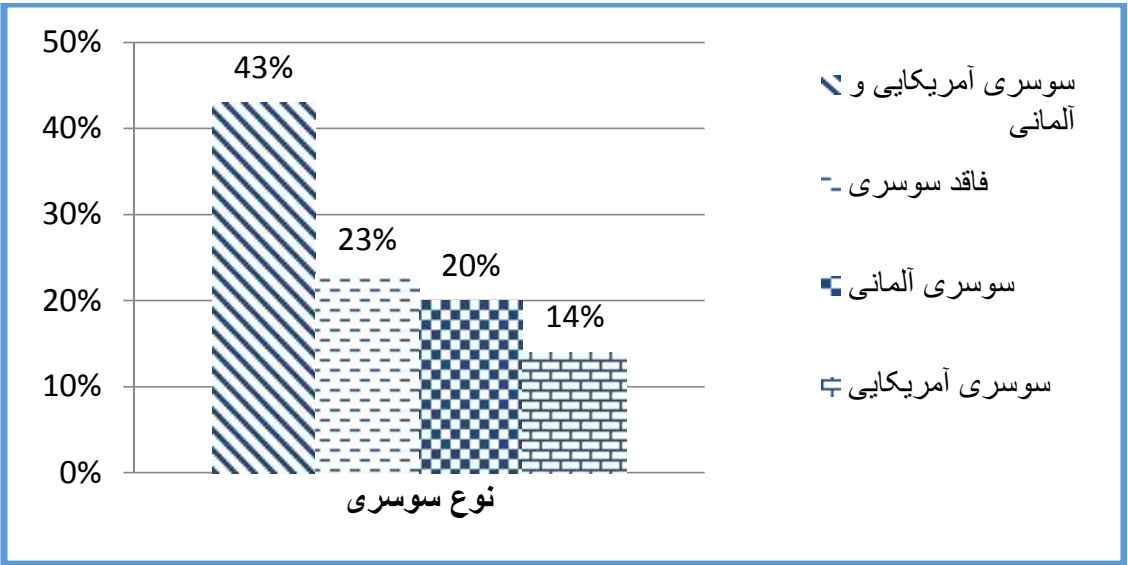

نمودار F: رصد آلودگى منازل بيماران به انواع مختلف سوسرى هاى رايج در اماكن انسانى 


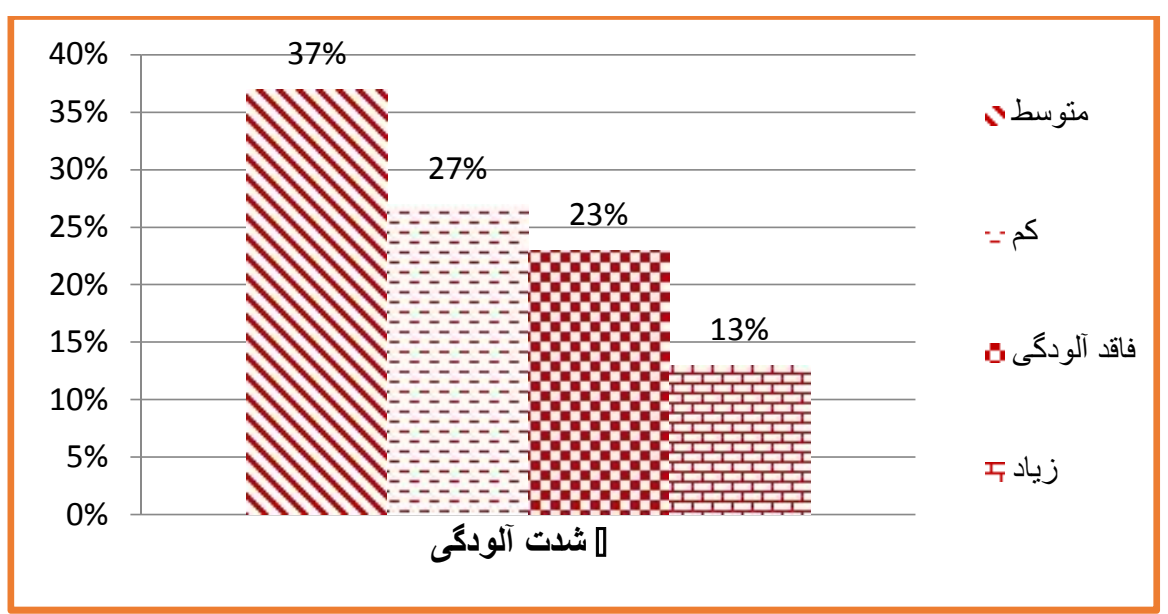

نمودار ه: شدت آلودگى منازل مورد بررسى به انواع مختلف سوسرى هاى رايج خانكى

شدت آلود گى: كم تعداد سوسرى كمتر از هاعدد در هر تله جسبان، شدت آلودگى متوسط: هץ-9 عدد سوسرى در هر تله جسبان،

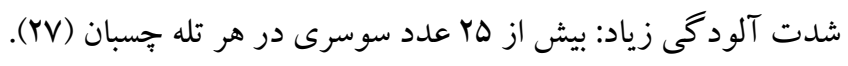

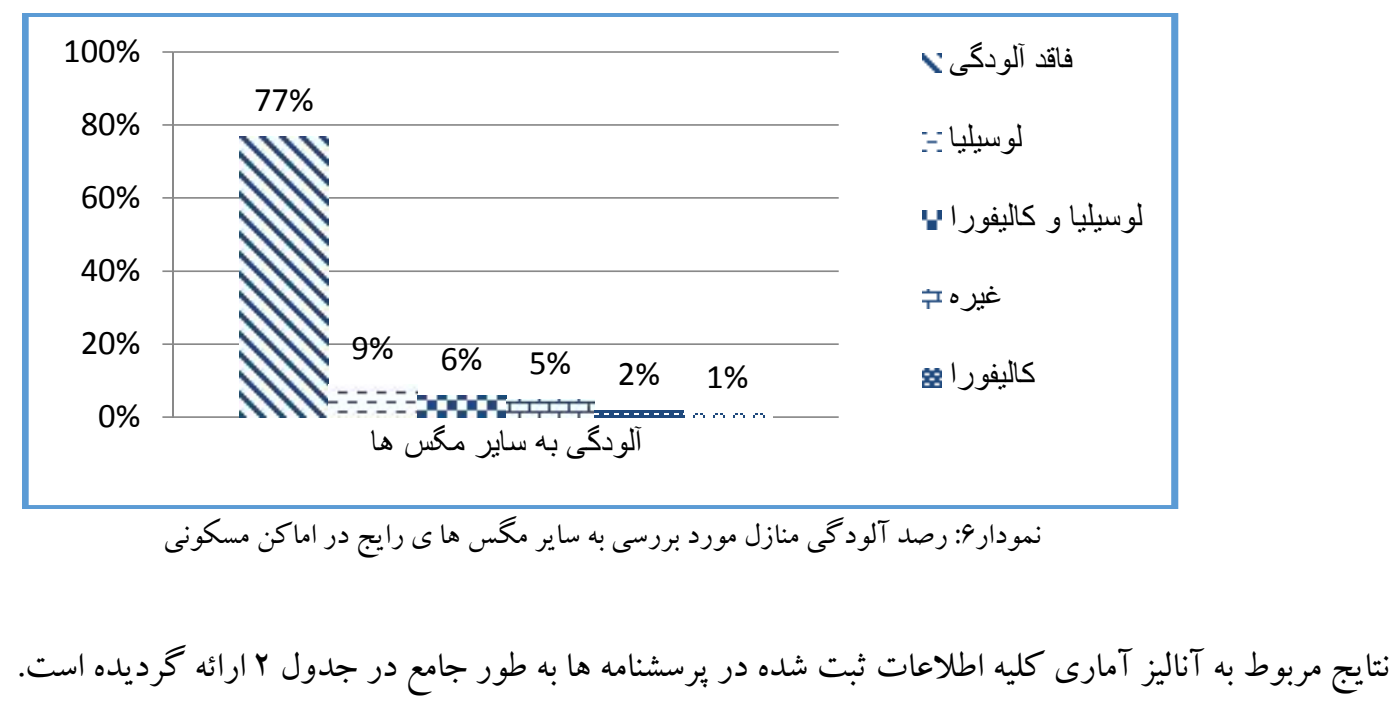


جدول r: آناليز آمارى نتايج استخراج شده از داده هاى برسشنامهبر رسى إيدميولوزيكك عوامل تاثير گذار بر بروز آسم و آلرزى با تاكيد بر بند بايان آلرزن در

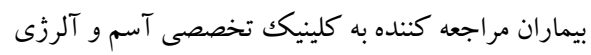

\begin{tabular}{|c|c|c|c|c|c|}
\hline رديف & مختلف & ارتباط بين = & $2 \pm$ & Pvalue & توضيحات \\
\hline 1 & كك در منازل & محل زندگى(شهرو روستا) & + & $\% \cdots \wedge$ & از منازل شهرى هيج ككى صيد نغرديد \\
\hline r & يشه در منازل & محل زندگى(شهرو روستا) & + & $\% r$ & 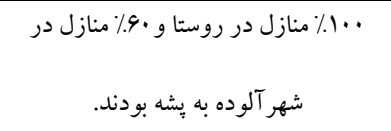 \\
\hline$r$ & مخس خانحى در منازل & محل زندگى(شهرو روستا) & + & $\% \cdots$ & 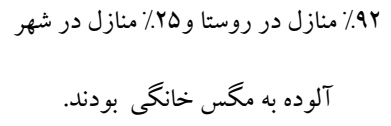 \\
\hline r & آفات انبارى در منازل & محل زندگى(شهرو روستا) & - & $\cdot / \mathrm{Nrq}$ & 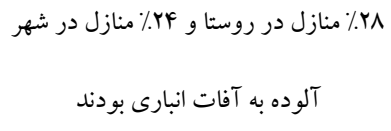 \\
\hline$\Delta$ & 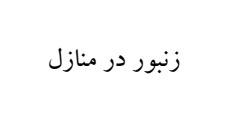 & محل زندگى(شهرو روستا) & + & 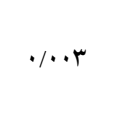 & 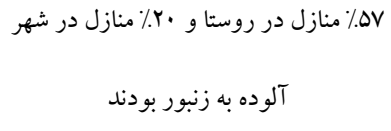 \\
\hline 9 & 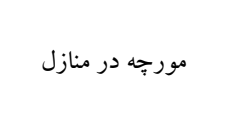 & محل زندگى(شهرو روستا) & - & $\cdot / \cdot v 1$ & 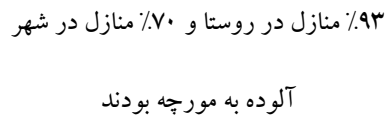 \\
\hline$\checkmark$ & ل الارو بروانه در منازل & محل زندگى(شهرو روستا) & + & $\% r$ & آr٪ منازل در روستا و זّ٪ منازل در شهر \\
\hline$\wedge$ & خرمخس در منازل & محل زندگى(شهرو روستا) & + & $\cdot \cdots$ & 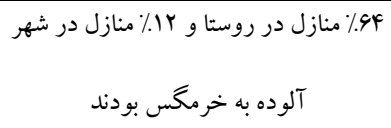 \\
\hline 9 & ماهى نقره ايى در منازل & محل زندگى (شهرو روستا) & - & $\cdot / \mu \cdot 1$ & 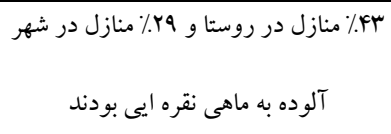 \\
\hline 1. & Moth flies & محل زندگى (شهرو روستا) & - & $\% \cdot \Delta r$ & 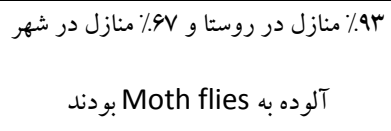 \\
\hline 11 & سوسرى در منازل & محل زندگى(شهرو روستا) & - & $\cdot / 4 \cdot \mu$ & 194\% منازل در روستا و V9٪ منازل در شهر \\
\hline ir & نوع سوسرى در منازل & محل زندگى(شهرو روستا) & - & $\cdot /$ TKF & $\begin{array}{l}------------------ \\
\end{array}$ \\
\hline
\end{tabular}




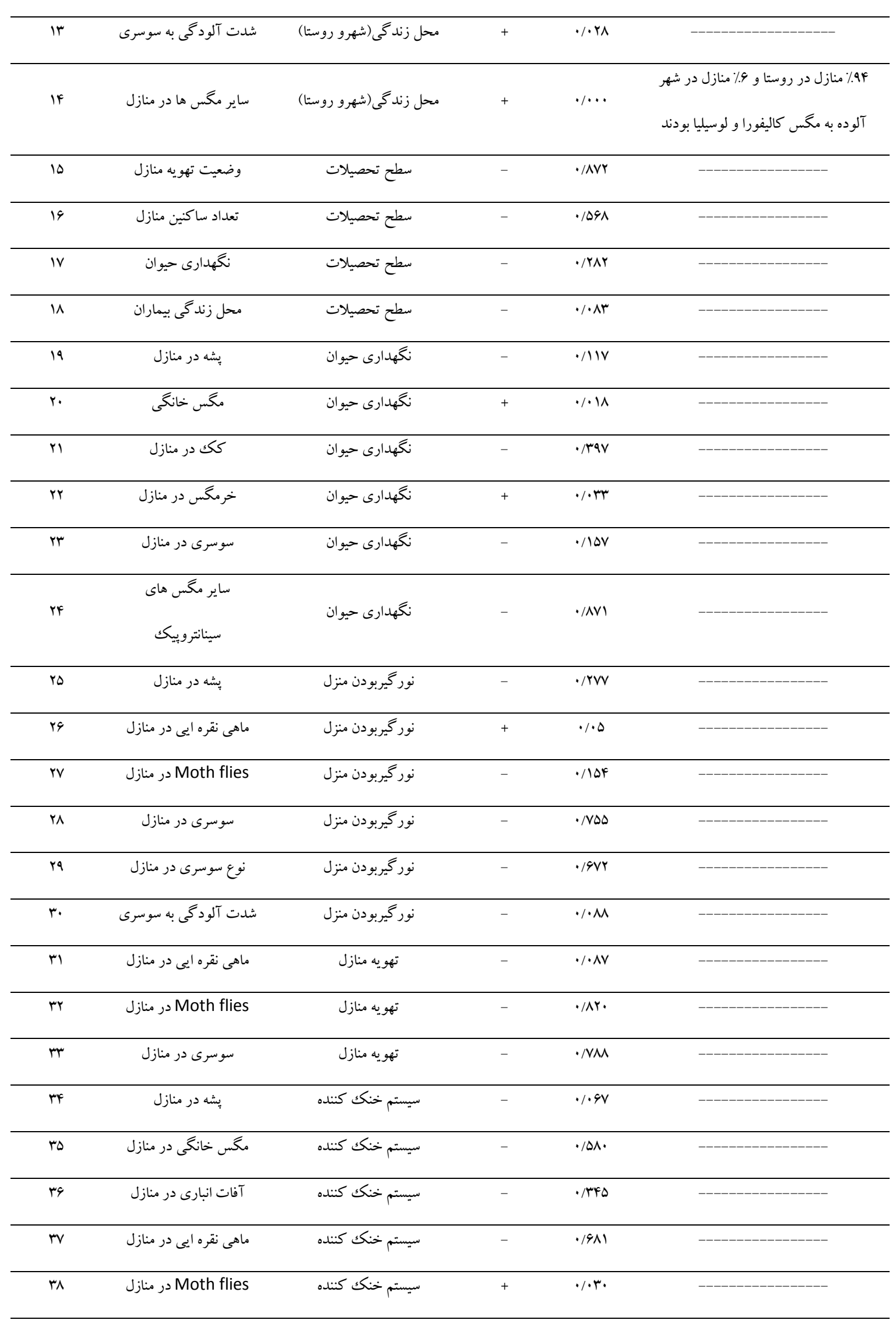


^مبراسى ايِيدميولوَّيك عواهل...

\begin{tabular}{|c|c|c|c|c|c|}
\hline ma & سوسرى در منازل & سيستم خنك كننده & + & 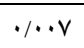 & ----------------- \\
\hline f. & حضور مايت & محل زندگى (شهرو روستا) & + & $\% \cdot \cdot 1$ & هץ\%٪ منازل در روستاو 1\% منازل در شهر \\
\hline 41 & حضور مايت & نغهدارى حيوان & - & $\cdot / r \Delta r$ & (--------------- \\
\hline kr & حضور مايت & وضعيت نور منزل & + & $\cdot \cdots$ & ------------------- \\
\hline kr & حضور مايت & وضعيت تهويه & + & $\% \cdots$ & -----------_----- \\
\hline kq & حضور مايت & نوع يوشش منزل & - & $\cdot / r \cdot 4$ & ---_---_--------- \\
\hline fo & حضور مايت & سيستم خنك كننده & - & /AFD & ----------------- \\
\hline kq & حضور مايت & تعداد ساكنين & - & $\cdot / r \Delta \Lambda$ & -------------------- \\
\hline
\end{tabular}


عـلاوه بـر اين نتـايج نشـان داد كـهـ بـين نخهـدارى حيـوان و

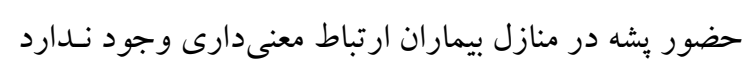

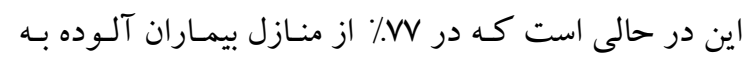

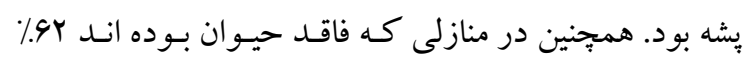

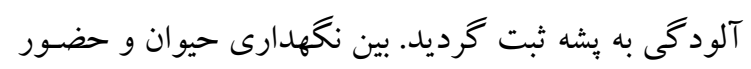

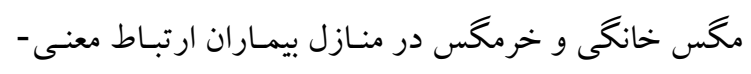

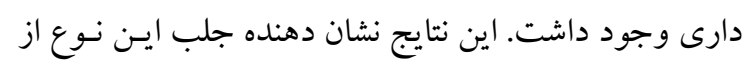
دوبالان به حيوان و محل هاى نخهـدارى حيو انـات در منـازل

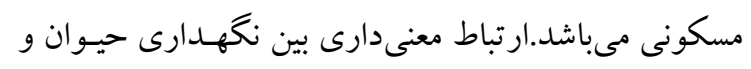

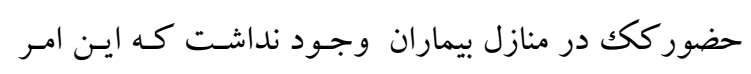

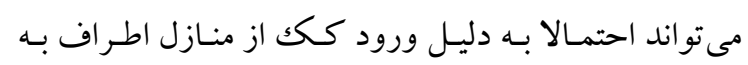

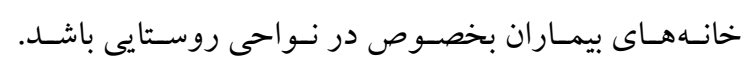

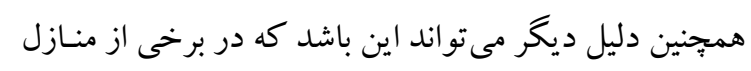

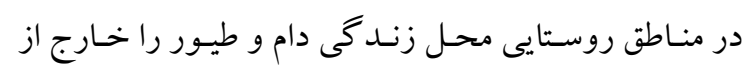

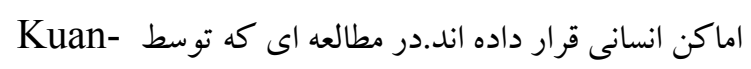

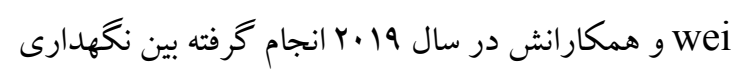

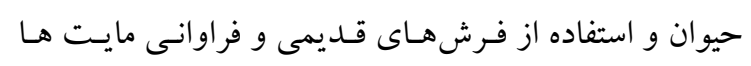
ارتباط معنى دارى وجود دارد (11).

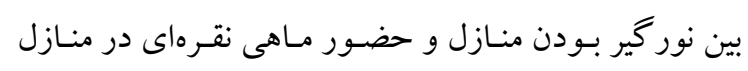

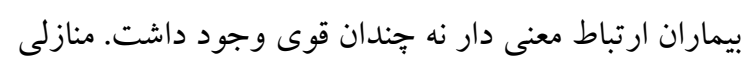

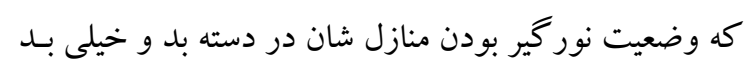

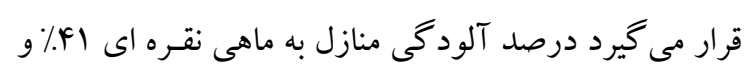

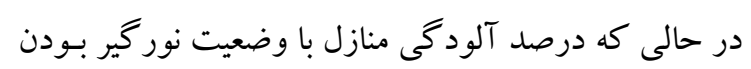

$$
\text { خوب و خيلى خوب هوب٪ بود. }
$$

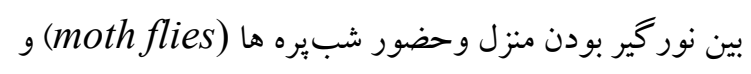
سوسرىها در منازل بيماران ارتباط معنى دار وجود نداشت فئ.

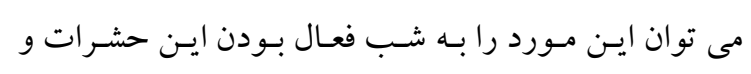

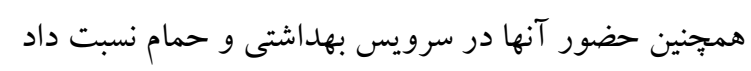
كه عموما تاريكك و مرطوب مى باشد و نور آنها كم است.

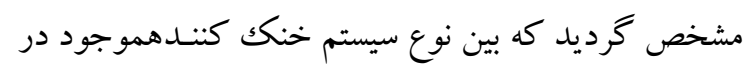
ساختمان و حضورشب بره ها و سوسرى ها در منازل بيماران

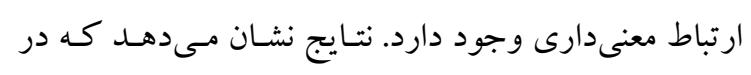

\section{بحث}

شرايط فيزيكى اماكن مسكونى مانند وضعيت تهويه، متوسط

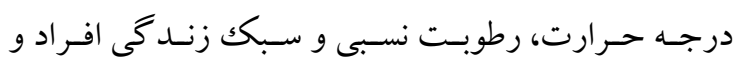

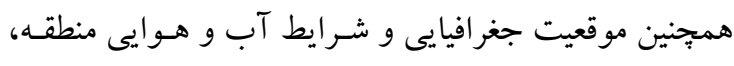

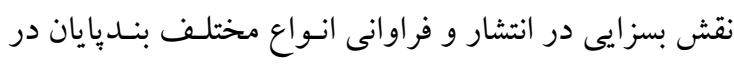
داخل اماكن دارد.نتايج مطالعهحاضر نشان داد كـه در منازل

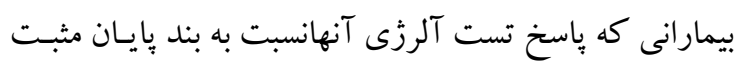

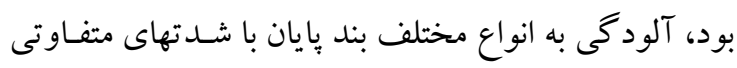

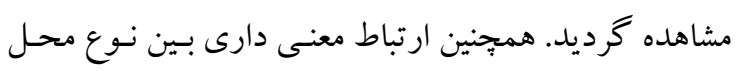

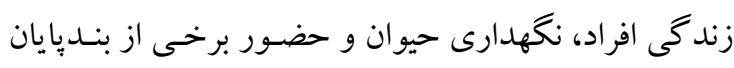
در داخل اماكن وجود داشت.

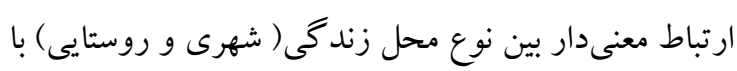

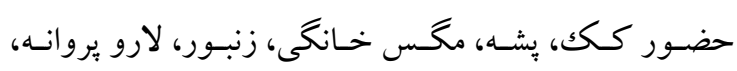

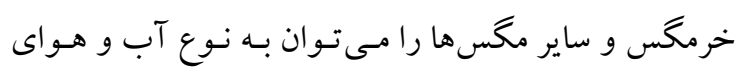

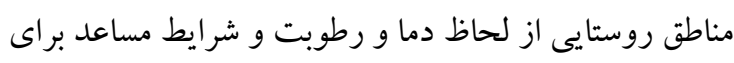

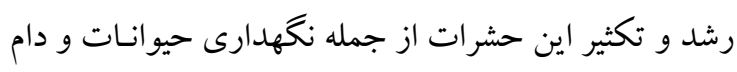

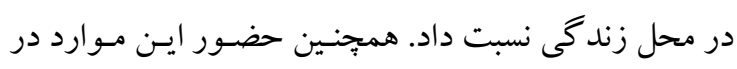

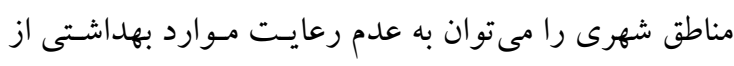

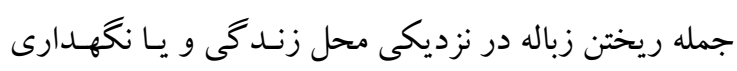

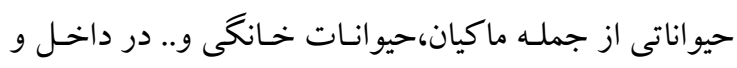

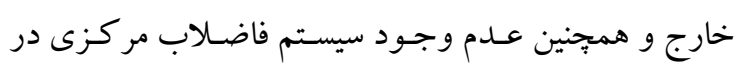
برخى مناطق و وارد شدن فاضلاب به كوجهه ها نسبت داد.

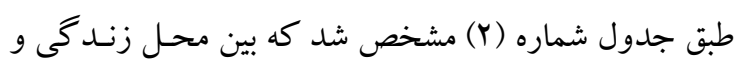

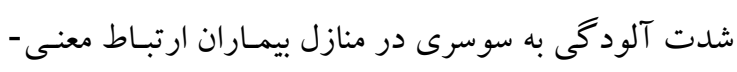
دارى وجود دارد و مىتوان اين كونه تعبير نمود كه عليـرغم

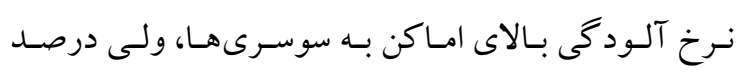

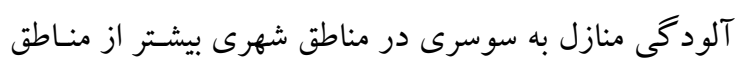

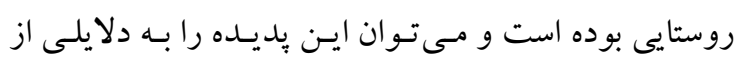

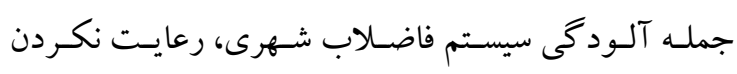

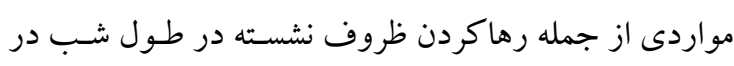

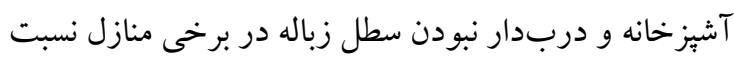

داد. 
شهرى( (1) بود. بين وضعيت نور منازل و وضعيت تهويـه بـا وجود مايـت ارتبـاط بسـيار شـديد وجـود داشـت، كه ..1\% منازلى كه در آنها مايت صيد شده بود داراى وضعيت بـد و بسيار بد از نظر نـور و تهويـه بودنـد.در VV درصـد از منـازل مورد مطالعه آلود گى به سوسرى مشاهده شد و طبق مطالعه -

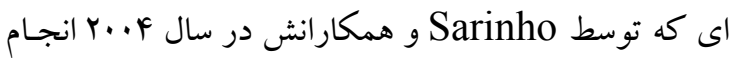

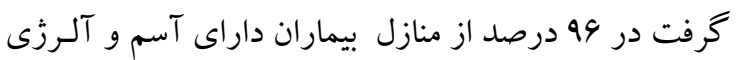

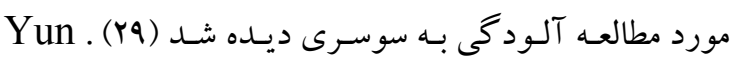

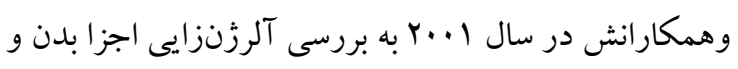
مو اد استخر اجى از مدفوع سوسرى آلمانى يرداختنـد در ايـن إنـ

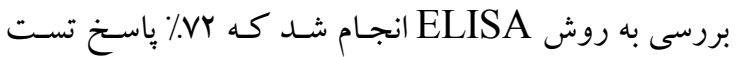
آنتى بادى نسبت به سوسرى آلمانى مثبت شد يافته ها تفاوت

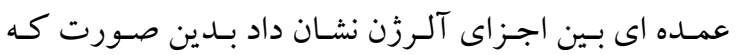

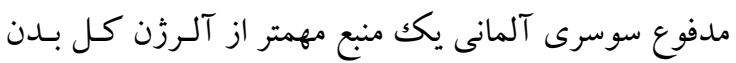
در بيمارىهاى آلرزيكك تنفسى است. ايشان نقش ايـن هيره

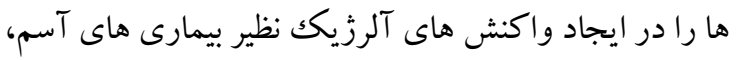

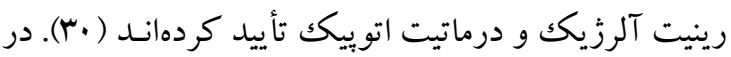
مطالعهاى كـه توسط Kim MK و همكـار انش در سـال

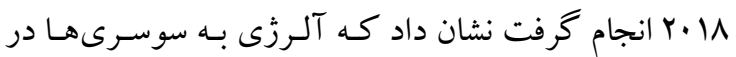
مناطق آلوده بيشتر اسـت و منـاطقى كـه در سطح بـايين تر اجتماعى - اقتصادى قرار دارند به طور مستقل با حساسيت به آلرزن هاى سوسرى ها ارتباط معنى دارى دارند (.T).

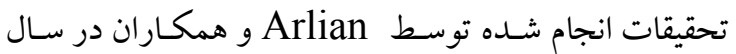
l9AVV نشان مىدهد كه مهمترين آلرزن مورد نظر براى ايجاد

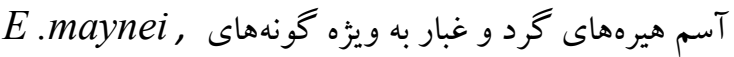
Dمس باشـند(اس,, farinae , D. pteronyssinus

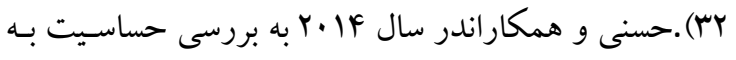

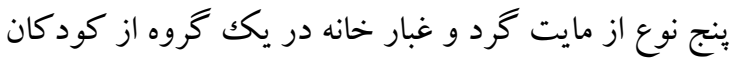

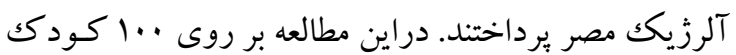

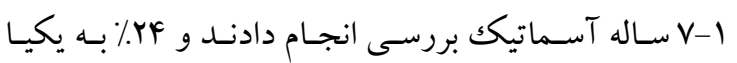

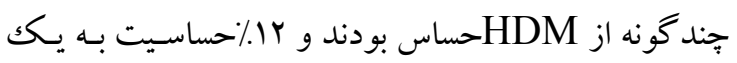

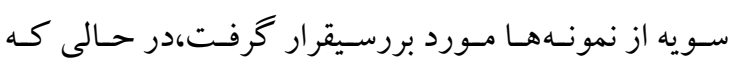

منازلى كه داراى سيستم خنك كننده نيستند ميزان آلودكى

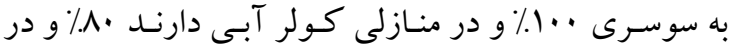
منازلى كه كولر كازى دارند اين نرخ به •بَ٪ كاهش مى يابد. سوسرى ها جهت رشد و نمـو خـود بـه محيطهـاى گر مر و

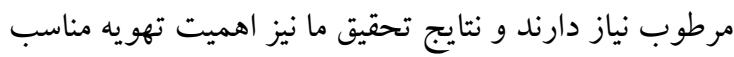

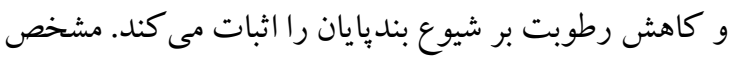

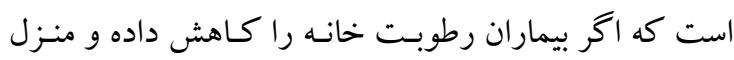
خنك تر باشد وفور بند بايان بخصوص سوسرىها در داخل داخل

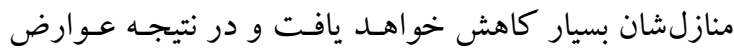
ناشى از حضور آنان در منازل نيز بـهـ حـــاقل خو اهـــ رسـيد.

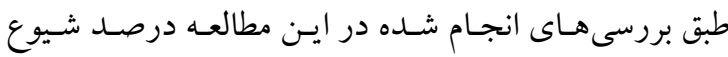

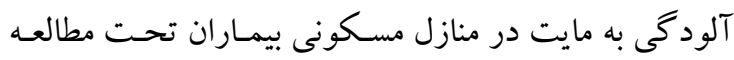
بسيار بايين بود (هـ/) اين امر رامىتوان بـه دلايـل متعـدىى

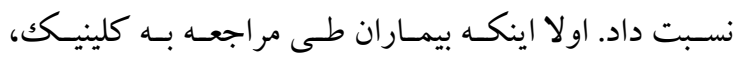
آموزشهايى توسط يزشك دريافت كرده و انجام دادهانـد، از جمله مصرف داروهـاى ضـد آلـرزى، شستشـوى لبـاس، ملحفهها، تشك و... و يا آفتاب دادن وسايلى كه بيمار با آنها

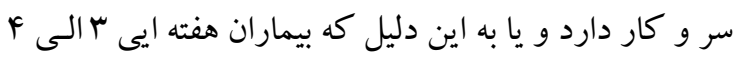

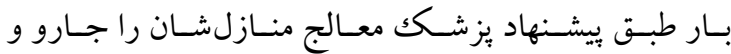
غبارروبى مىنمودند. همجِنين در خصوص آن دسته مواردى كـه در منـازلشـان مايـت جداسـازى و شناسـيى شـد، طبق فيق يرس سشايى كه در زمان نمونه گيرى از بيمار صورت گرفت مشخص شد كه اين افراد در طول هفته منازلشان را بيشتر بـا جارو دستى جارو مىنمودند و استفاده از جـارو برقى را بـهـ ماهى الى ب بار مو كول مى كردند. كه اين امر باعث ازدياد

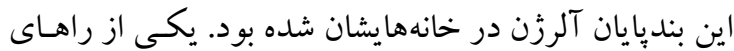
كنترل و ييشگيرى از وفور بالاى مايتهـاى آلرزن استفاده مكرر از جـاروبرقى و كـاهش رطوبـت و افزايش نـوردهى ونى

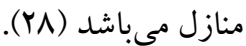
بين محل زنـدكى (شهر و روسـتا) و حضـور مايـت ارتبـاط

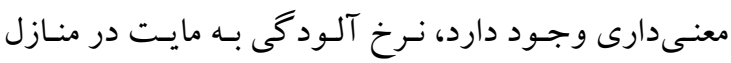

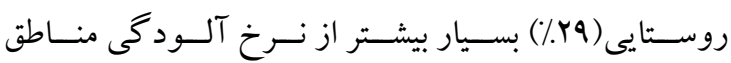


عوارض آلرزيـك در ايـن گونـه از بيمـاران حسـاس شـوند.

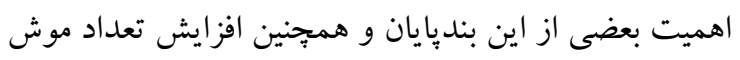

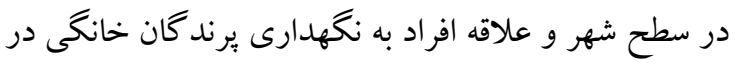

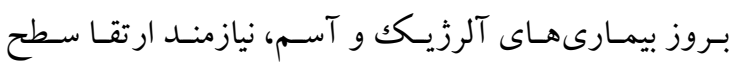

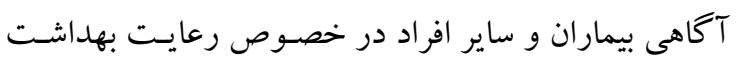

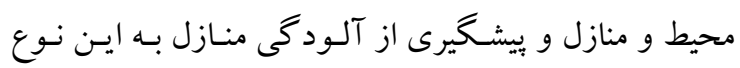

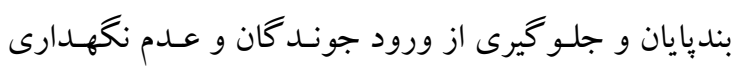

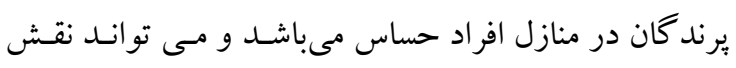

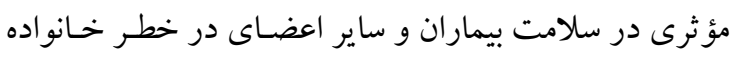
آنها ايفاء نمايد.

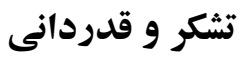

از همكارى تمام بيماران شركت كننده در مطالعه و اعضـاى

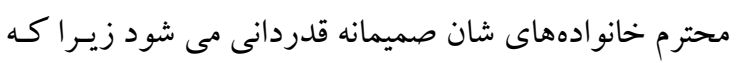

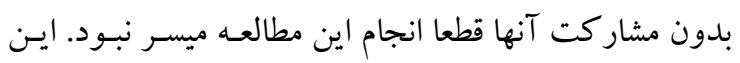

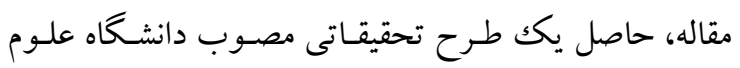

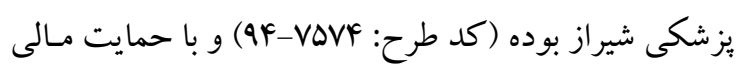
معاونت يُزوهشياين دانشگاه به انجام رسيد.
حساسيت به دو يا سه گُنه در ^/ تشخيص داده شد. دوازده درصد ازكود كان حسـاس بـ D. pteronyssinus و 11\% حساس به D. farina

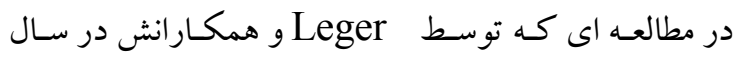

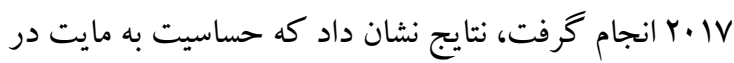
بيش از نيمى از كودكـان مبتلا بـه آلرزى در منطقـه مـورد

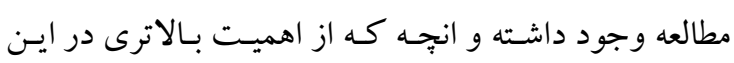

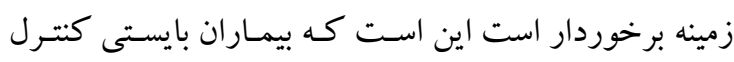
مايتها را در منازل مسكونى مد نظر داشته باشند (MY).

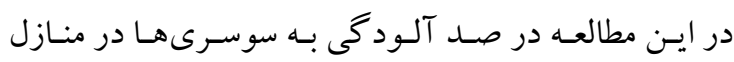

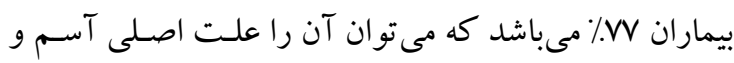

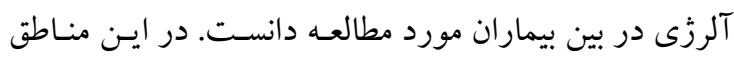
هِايش و كنترل سوسرىها از طرف مقامات بهداشتى منطقـه جهت تامين سلامت عمومى بسيار حائز اهميت است (ه) (r). نتيجه كيرى اين مطالعات نشان دهنده آن است كه گر جه شيوع مايتهـا در منازل بالا نمىباشد ولى شيوع آلرزٔنهاى مرتبط با مايت -

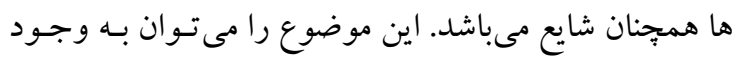

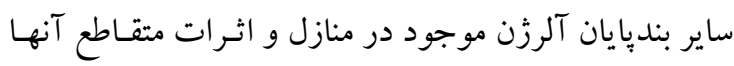
بر ايجاد آلرزى در بيماران نسبت داد. همجنين در اين مطالعه

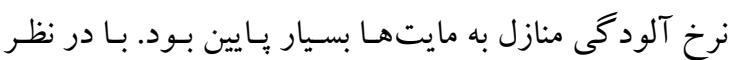

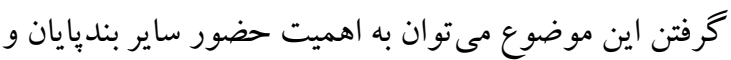

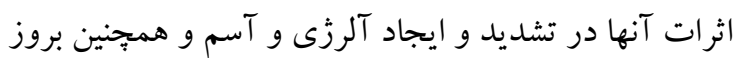
واكنش متقاطع (Cross-reactivity) يى برد.

در مجمـوع بــا توجـهـ بـه وفور بـالا و قابـل توجـه دو راسـته Diptera و حضور نسبتا بالاى وفور برخى از بنديايان مانـــ ( مورجـه، ماهى نقره اي و ...) در منازل بيماران شهر شـيراز، مسى توانــ

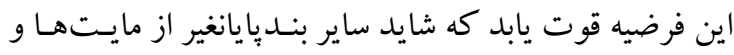
سوسرىها كه در منازل حضور دارند بتوانتــ باعـث تشـديد 


\section{References}

1. Arlian LG. Arthropod allergens and human health. Annu Rev Entomol 2002;47:395-433.

2. Jeong KY, Hong CS, Yong TS. Domestic arthropods and their allergens. Protein Pept Lett 2007;14(10):934-42.

3. Ree H. Medical Entomology: Medical Arthropodology. 4th ed. Seoul: Komoonsa, 2005: 345-90.

4. Saad E-Z, Hussien R, Saher F, Ahmed Z. Acaricidal activities of some essential oilsand their monoterpenoidal constituents against house dust mite, Dermatophagoides pteronyssinus (Acari: Pyroglyphidae). J Zhejiang Univ Sci B 2006;7:957-62.

5. Soltani A, Azizi K, Saleh V, Dabaghmanesh T. The fauna and distributionof house dust mites in residential homes of Bandar Abbas District, Southern Iran. Exp Appl Acarol 2011;54:269-76.

6. Amoli K, Cunnington A. House dust mites in Iran. Clin Exp Allergy 1977;7:93-101.

7. Chen K-W, Zieglmayer P, Zieglmayer R, Lemell P, Horak F, Bunu CP, et al. Selection of house dust mite-allergic patients by molecular diagnosis may enhance success of specific immunotherapy. J Allergy Clin Immunol 2019;143:1248-52. e12.

8. Htut T, Higenbottam TW, Gill GW, Darwin SR, Anderson PB, Syed N. Eradication of house dust mite from homes of atopic asthmatic subjects: a double-blind trial. J Allergy Clin Immunol 2001;107:55-60.

9. Jeong KY, Park J-W, Hong C-S. House dust mite allergy in Korea: the most important inhalant allergen in current and future. Allergy Asthma Immunol Res 2012;4:313-25.

10. Linneberg A. Are we getting enough allergens? Int Arch Allergy Immunol 2008;147:93100 .

11. Alipour A. Frequency of house dust mites in bedroom of 5 to 8 years old patients with asthma in referred to asthma and allergy clinic of bou ali sina hospital in 2017-18 [dissertation]. Sari: School of Medicine, Mazandaran University of Medical Sciences; 2018. [In Persian]

12. Baumholtz MA, Parish LC, Witkowski JA, Nutting WB. The medical importance of cockroaches. Int J Dermatol 1997;36:90-6.

13. Cochran DG. World Health Organization. Cockroaches: their biology, distribution and control. Geneva: World Health Organization, 1999.

14. Roth LM, Willis ER. The medical and veterinary importance of cockroaches. The medical and veterinary importance of cockroaches. 1957.

15. Glesner J, Filep S, Schulten VM, Frazier A, Vailes LD, Wünschmann S, et al .Potency of german cockroach extracts for ige reactivity depends on allergen content and allergen-specific IgE titers of the cockroach allergic patient. J Allergy Clin Immunol 2018;141:AB108.

16. Glesner J, Filep S, Vailes LD, Wünschmann S, Chapman MD, Birrueta G, et al. Allergen content in German cockroach extracts and sensitization profiles to a new expanded set of cockroach allergens determine in vitro extract potency for IgE reactivity. J Allergy Clin Immunol 2019;143:1474-81. e8. 
17. Birnbaum J, Guilloux L, Charpin D, Vervloet D. Cockroach allergens. The Lancet 1991;337:249.

18. Rabito FA, Carlson JC, He H, Werthmann D, Schal C. A single intervention for cockroach control reduces cockroach exposure and asthma morbidity in children. J Allergy Clin Immunol 2017;140:565-70.

19. Brenner RJ, Kramer RD. Medical and Veterinary Entomology (Third Edition). Chapter 6 - Cockroaches (Blattaria) 2019; 2019:61-77.

20. Kim MK, Jeong JS, Han K, Baek KH, Song K-H, Kwon H-S. House dust mite and Cockroach specific Immunoglobulin E sensitization is associated with diabetes mellitus in the adult Korean population. Sci Rep 2018;8:2614.

21. Lassiter M, Fashing N. House dust mites in Williamsburg, Virginia. Va Med 1990;117:152-7.

22. Kern R. Dust sensitization in bronchial asthma. Med Clin North Am 1921;5:751-8.

24. Fakoorziba MR, Kadivar AA, Alipour H. Identification of house dust mite species (Acarina: Astigmata) in producing allergy and asthma in residential places in south of Iran. $\mathbf{J}$ Exp Zool 2012;15:609-12.

25. Ballard JB, Gold RE. The effect of selected baits on the efficacy of a sticky trap in the evaluation of German cockroach populations. J Kans Entomol Soc 1982:86-90.

26. Colloff M, Spieksma FTM. Pictorial keys for the identification of domestic mites. Clin Exp Allergy 1992;22:823-30.

27. Shah V, Learmount J, Pinniger D. Infestations of german cockroach blattella germanica in multi-occupancy dwellings in a london borough - a preliminary study into the relationship between environment, infestation and control success. Proceedings of the Second Inteional Conference on Urban Pests 1996;203-9.

28. Munir A, Einarsson R, Dreborg S. Vacuum cleaning decreases the levels of mite allergens in house dust. Pediatr Allergy Immunol 1993;4:136-43.

29. Sarinho E, Schor D, Veloso M, Rizzo J. There are more asthmatics in homes with high cockroach infestation. Braz J Med Biol Res 2004;37:503-10.

30. Yun YY, Ko SH, Park JW, Lee IY, Ree HI, Hong CS. Comparison of allergenic components between German cockroach whole body and fecal extracts. Ann Allergy Asthma Immunol 2001;86:551-6.

31. Arlian L, Bernstein I, Gallagher JS. The prevalence of house dustmites, Dermatophagoides spp, and associated environmental conditions in homes in Ohio. J Allergy Clin Immunol 1982;69:527-32.

32. Platts-Mills TA, Chapman MD. Dust mites: immunology, allergic disease, and environmental control. J Allergy Clin Immunol 1987;80:755-75.

33. Hossny E, El-Sayed S, Abdul-Rahman N. Sensitivity to five types of house dust mite in a group of allergic Egyptian children. Pediat Aller Imm Pul 2014;27:133-7.

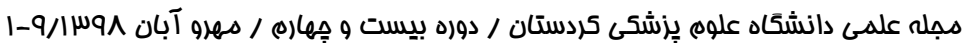


34. Leger D, Bonnefoy B, Pigearias B, de La Giclais B, Chartier A. Poor sleep is highly associated with house dust mite allergic rhinitis in adults and children. Allergy Asthma Clin Immunol 2017;13:36.

35. Shahraki GH, Parhizkar S, Nejad AR. Cockroach infestation and factors affecting the estimation of cockroach population in urban communities. Int J Zool 2013;2013:649089. 